\title{
Assessment of Water and Sediment Quality of Noakhali Canal, Noakhali, Bangladesh
}

\author{
Shurovi Zaman ${ }^{1}$, Md Kamrul Hasan ${ }^{1}$, Sayma Khanom², Tasrina Rabia Choudhury ${ }^{3}$ and Mohammad Mahbub \\ Kabir ${ }^{1,4 *}$ \\ ${ }^{1}$ Department of Environmental Science and Disaster Management, Noakhali Science and Technology University, Bangladesh
}

${ }^{2}$ Department of Soil, Water \& Environment, University of Dhaka, Bangladesh

${ }^{3}$ Analytical Chemistry Laboratory, Chemistry Division, Atomic Energy Centre, Bangladesh

${ }^{4}$ Department of Environmental Sciences, Jahangirnagar University, Bangladesh

Submission: January 28, 2019; Published: February 25, 2019

*Corresponding author: Mohammad Mahbub Kabir, Department of Environmental Science and Disaster Management, Noakhali Science and Technology University, Noakhali-3814, Bangladesh

Abstract

The present investigation has been conducted to examine the surface water and sediment quality especially some selected heavy metals of Noakhali canal adjacent to Bangladesh Small Cottage and Industries Corporation (BSCIC), Begumganj, Noakhali, Bangladesh. The concentrations of heavy metals in water and sediment have been analyzed by means of Flame Atomic Absorption Spectrophotometer (FAAS). The mean values of pH, EC, TDS, P, K, SO42-, Cl-, NaCl and Temperature in surface water were $6.744,1302 \mu \mathrm{S} / \mathrm{cm}, 634.9 \mathrm{mg} / \mathrm{L}, 0.0835 \mathrm{mg} / \mathrm{L}, 0.466 \mathrm{cmol}+, 2.978 \mathrm{mg} / \mathrm{L}$, $328.289 \mathrm{mg} / \mathrm{L}, 2.46 \mathrm{mg} / \mathrm{L}$ and $26.84 \mathrm{OC}$, respectively. The average concentration of Fe and $\mathrm{Mn}$ in surface water was $0.55 \mathrm{mg} / \mathrm{L}$ and $0.4081 \mathrm{mg} / \mathrm{L}$ and the rest of heavy metals were found below detection limit. The mean values of $\mathrm{pH}, \mathrm{EC}, \mathrm{OC}, \mathrm{OM}, \mathrm{TN}, \mathrm{P}, \mathrm{K}, \mathrm{S}$ in sediment sampling sites were $6.83,565.5,2.427 \%, 4.185 \%, 0.21 \%, 43.1 \mu \mathrm{g} / \mathrm{g}, 0.5 \mathrm{meq} / 100 \mathrm{gm}, 157 \mu \mathrm{g} / \mathrm{g}$, respectively. The order of heavy metals in sediment was $\mathrm{Fe}$ $>\mathrm{Mn}>\mathrm{Zn}>\mathrm{Pb}>\mathrm{Cu}$. Almost all water and sediment quality parameters and heavy metals were within acceptable limit prescribed by national and international standards except Fe, EC, OC, OM, S, P and K. According to Sediment Quality Guideline, sediment samples were not polluted for Pb, $\mathrm{Cu}, \mathrm{Mn}$, and $\mathrm{Zn}$. The geo-accumulation index (Igeo) showed no pollution for most of the sampling sites for all studied heavy metals except $\mathrm{Fe}$. The Igeo value of Fe showed that the sediment was unpolluted to moderately polluted. Pollution Load Index (PLI) and Contamination Factor (CF) also showed no pollution for all the examined heavy metals. This study can be used as a baseline to monitor the quality of water and sediment of this canal which will help to preserve a healthy aquatic ecosystem.

Keywords: Heavy metals; Water and sediment quality; Geo- accumulation index, Contamination factor; Pollution load index; Noakhali canal Abbrevations: BSCIC: Bangladesh Small Cottage and Industries Corporation; FAAS: Flame Atomic Absorption Spectrophotometer; Igeo: GeoAccumulation Index; PLI: Pollution Load Index; CF: Contamination Factor

\section{Introduction}

Heavy metal pollution is considered to be a serious threat to any aquatic ecosystems owing to its toxicity, long-term persistence, ubiquity, non-biodegradability, and subsequent accumulation into the food chain [1]. Heavy metals enter these aquatic systems mainly through natural inputs such as weathering and erosion of rocks and anthropogenic sources including industrial, urban and agricultural activities, sewage disposal and terrestrial runoff [2]. Numerous industries have been set up in many cities including the quantity of new industries is consistently expanding [3]. Bangladesh is one of the most polluted countries, which currently holds 1176 industries that discharge about 0.4 million $\mathrm{m}^{3}$ of untreated waste to the rivers in a day [4]. As a result of rapid urbanization and industrialization in Bangladesh, economic growth is increasing but the environment is changing extremely
[5]. So, study on heavy metals as well as physical and chemical qualities of water and sediment like $\mathrm{pH}, \mathrm{EC}, \mathrm{TDS}, \mathrm{P}, \mathrm{K}, \mathrm{SO}_{4}{ }^{2-}, \mathrm{Cl}$;, $\mathrm{OM}$, OC, TN in rivers, lakes, fish and sediment have been a noteworthy environmental core interest which are required for the growth of phytoplankton, zooplankton and fish [6-9]. The identification and quantification of heavy metal in aquatic environment is an imperative environmental issue and the distribution processes of heavy metals are controlled by a dynamic set of physicalchemical equilibria, i.e. metal solubility is chiefly controlled by $\mathrm{pH}$, concentration and type of ligands and chelating agents, oxidationstate of mineral components and the redox condition of the system [10-11]. Noakhali canal receives industrial wastewater directly from industries and also domestic and agro-chemical wastes which contribute heavy metal pollution and deterioration of other 
water and sediment quality parameters. However, to the best of our knowledge, no significant studies have been undertaken to investigate the pollution level of the Noakhali canal situated in Noakhali District of Bangladesh. The present investigation has been conducted to observe the status of selected heavy metals in water and sediment of Noakhali canal. Moreover, determination of the general water and sediment quality of Noakhali canal has also been conducted.

\section{Materials and Methods}

\section{Study area}

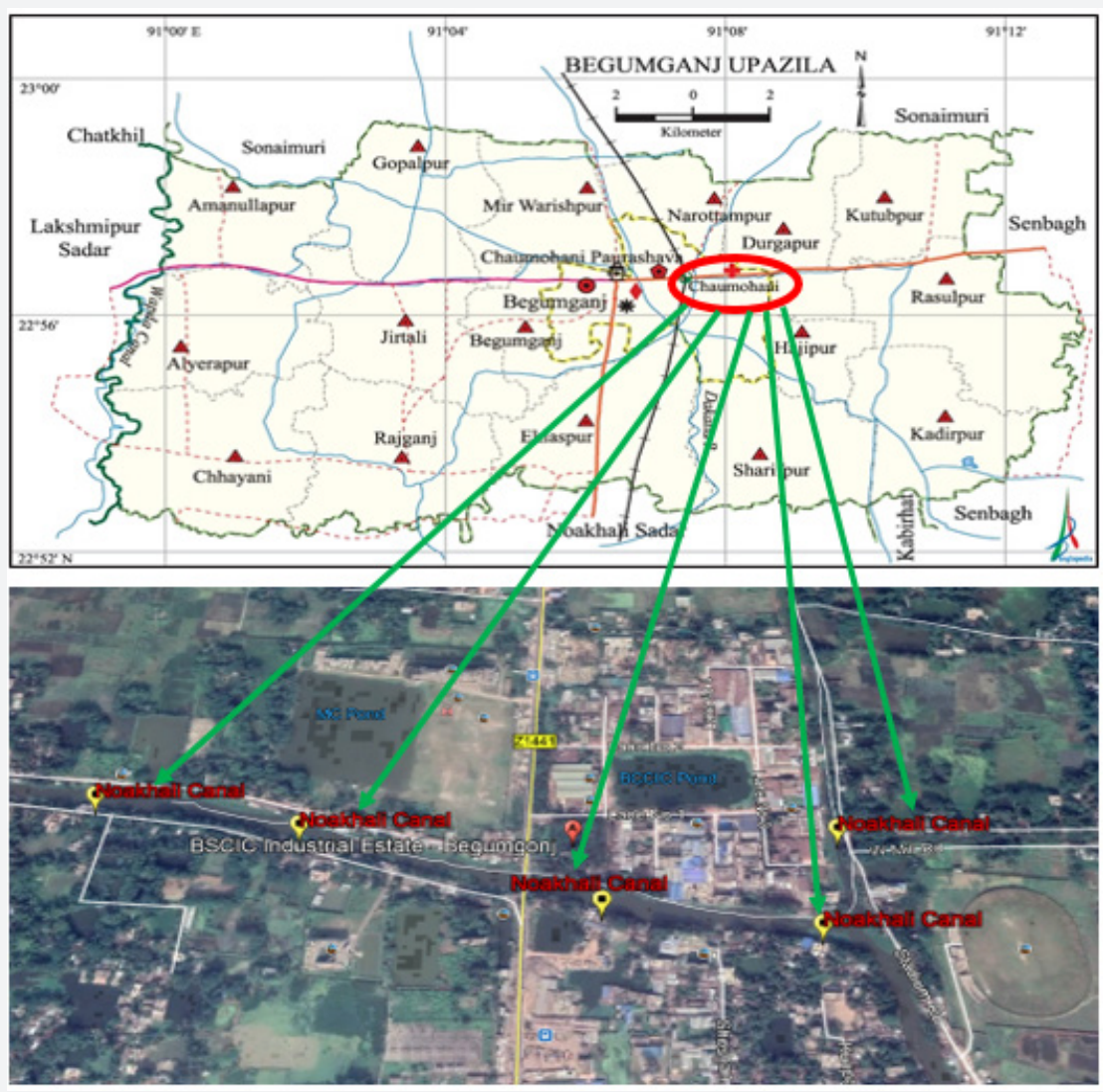

Figure 1: Map of study area (Noakhali canal surrounding BSCIC industrial estate).

The study area has been shown in Figure 1 which is located at the Mir Warishpur union under Begumgonj upazila of Noakhali District at $22^{\circ} 56^{\prime} 57.0^{\prime \prime} \mathrm{N}$ and longitude $91^{\circ} 06^{\prime} 18.6^{\prime \prime} \mathrm{E}$. It is situated beside the Dhaka-Noakhali highway road locally named as BSCIC Industrial Estate [12]. The samples were collected from ten different predetermined sampling sites from Noakhali canal which receives effluent from BSCIC Industrial State, Municipal areas, Roads and Highways and agricultural runoff water.

\section{Samples collection and preparation}

Ten water and ten sediment samples were collected from the predetermined sampling sites. Surface water samples were collected from the canal water about $10-20 \mathrm{~cm}$ below. In order to collect water and sediment samples plastic bottles $(500 \mathrm{ml})$ as well as polyethylene bags were used. For measurement of heavy metal concentration, $65 \%$ concentrated $\mathrm{HNO}_{3}$ acid was added to each sample instantly to bring the $\mathrm{pH}$ below 2 [13]. Sediment samples were taken at a depth of $0-10 \mathrm{~cm}$ and immediately transferred into polyethylene bags. Sediment samples were dried in a dry and dust-free place at room temperature in order to grind into fine powder before sieved under $2 \mathrm{~mm}$ mesh for storing in plastic container [14].

\section{Physico-chemical analysis of canal water}

The $\mathrm{pH}$ was measured with a pH meter (WTW pH 522, Germany). EC, TDS, $\mathrm{NaCl}$, and Temperature were measured by following the procedure of Richard (1954) with an Electrical Conductivity meter (Martin Bench, EC meter). P was measured with visible spectrophotometer Model (DR 3800- HACH) (APHA, 1998). K was measured by using the Flame Photometer. $\mathrm{SO}_{4}{ }^{2-}$ was measured with a spectrophotometer at $535 \mathrm{~nm}$ wavelength.

\section{Physico-chemical analysis of canal sediment}

pH was measured with pH meter WTW pH 522, Germany from the suspension of sediment water. EC was measured by using EC meter (Martin Bench EC meter). OC, OM and TN were measured by using the Walkley and Black oxidation method. P was measured by following the method of Bray and Kurtz when the sample $\mathrm{pH}<7.0$ and the Olsen method when the sample $\mathrm{pH}>7.0$. $\mathrm{K}$ was measured from the suspension of sediment water reading 
by flame photometer. $\mathrm{SO}_{4}{ }^{2-}$ was measured by a spectrophotometer at $535 \mathrm{~nm}$ wavelength.

\section{Estimation of heavy metals in water and sediment}

Concentrated $\mathrm{HNO}_{3}$ acid was used to digest the water samples, described by APHA [13]. Concentrated $\mathrm{HNO}_{3}$ acid and concentrated $\mathrm{HClO}_{4}$ acid were used to digest the sediment samples [15] and samples were analyzed by Flame Atomic Absorption Spectrophotometer (Model: AA-7000; Shimadzu, Japan) in order to detect heavy metals like $\mathrm{Pd}, \mathrm{Cu}, \mathrm{Cd}, \mathrm{Fe}, \mathrm{Zn}$ and $\mathrm{Mn}$ by following the manufacturer's instructions.

\section{Sediment quality assessment}

\section{Geo-accumulation index (Igeo)}

Muller [16] developed the Geo-accumulation index (Igeo) which is widely used in the assessment of metal contamination in sediment and soil by comparing current concentration with pre-industrial levels $[17,18]$.

Igeo is calculated using the following formula [15]:

Table 1: Index classification of sediment quality (Muller, 1981) [19].

$$
\text { Igeo }=\log (C n / 1.5 * B n)(1)
$$

where, $\mathrm{Cn}$ is the measured concentration of the metal $(n)$ in the sediment. $B n$ is the geochemical background of the metal $(n)$. The factor 1.5 is used for the possible variations of the background data due to lithological variations. Muller [19] classified Igeo values into seven classes in Table 1.

\section{Contamination factor (CF)}

The Contamination Factor (CF) and Contamination Degree (CD) are used to assess the pollution load of the sediment according to heavy metals [10]. CF for each metal was determined by the following formula [20]:

$$
C F=\frac{\text { Measured metal concentration }}{\text { Background concentration of the same metal }} \text {. }
$$

Where, $C D$ for each site was calculated as sum of all contamination factors [21]. Hakanson [20] has provided four grade ratings of sediment based on CF values (Table 1).

\begin{tabular}{|c|c|c|}
\hline Igeo value, Muller (1981) & Class & Sediment Quality \\
\hline$\leq 0$ & 0 & Unpolluted \\
\hline $0-1$ & 1 & Unpolluted to moderately polluted \\
\hline $1-2$ & 2 & Moderately to strongly polluted \\
\hline $2-3$ & 3 & Strongly polluted \\
\hline $3-4$ & 4 & Strongly to extremely polluted \\
\hline $4-6$ & 5 & Extremely polluted \\
\hline$\geq 6$ & 6 & Sediment quality \\
\hline $\mathrm{CF}$ values, Hakanson $(1980)[20]$ & Class & Low CF \\
\hline $\mathrm{CF}<1$ & 1 & Moderate CF \\
\hline $1 \leq \mathrm{CF}<3$ & 2 & Considerable CF \\
\hline $3 \leq \mathrm{CF}<6$ & 3 & Very high CF \\
\hline $\mathrm{CF} \geq 6$ & 4 & \\
\hline
\end{tabular}

\section{Pollution load index (PLI)}

Pollution Load Index (PLI) is used to find out the mutual pollution effect at different stations by the different elements in sediment and gives an assessment of the overall toxicity status of each sampling station. PLI for each site was determined by the following equation proposed by Tomlinson et al. [22].

$$
P L I=\sqrt[n]{C F 1 * C F 2 * C F 3 * \ldots \ldots C F * n}
$$

where, $C F$ is the contamination factor. $\mathrm{n}$ is the number of metals. The PLI value of $>1$ is polluted, whereas $<1$ indicates no pollution [23] which is quickly understood to compare the pollution status of different places.

\section{Results and Discussion}

\section{Physico-chemical characteristics of water of Noakhali Canal}

The values of water quality parameters in Noakhali canal at different sites have been given in Table 2 . The mean values of $\mathrm{pH}, \mathrm{EC}, \mathrm{TDS}, \mathrm{P}, \mathrm{K}, \mathrm{SO}_{4}{ }^{2-}, \mathrm{Cl}$, $\mathrm{NaCl}$ and Temperature were 6.744 ,
$1302 \mu \mathrm{S} / \mathrm{cm}, 634.9 \mathrm{mg} / \mathrm{L}, 0.0835 \mathrm{mg} / \mathrm{L}, 0.466 \mathrm{cmol}+, 2.978 \mathrm{mg} / \mathrm{L}$, $328.289 \mathrm{mg} / \mathrm{L}, 2.46 \mathrm{mg} / \mathrm{L}$ and $26.84^{\circ} \mathrm{C}$, respectively. The mean values of $\mathrm{pH}, \mathrm{TDS}, \mathrm{SO}_{4}{ }^{2-}, \mathrm{Cl}^{-}$and $\mathrm{NaCl}$ in the Noakhali canal were within the acceptable limit whereas the mean values of EC were higher than the acceptable limit compared to standard of Bangladesh for inland surface water [3]. Water containing TDS concentrations below $1000 \mathrm{mg} / \mathrm{L}$ is usually acceptable as per WHO standards. According to Nadia [24], water use for irrigation with high TDS value may reduce the production of crops. The mean value of P was $0.835 \mathrm{mg} / \mathrm{L}$. According to Stone and Thomforde [25], the phosphate level of $0.06 \mathrm{mg} / \mathrm{L}$ is favorable for fish which does not support the present study for the survival of fish in the study area. The mean value of potassium (K) was $0.466 \mathrm{mg} / \mathrm{L}$. Rahman \& Ahsan, observed $0.23 \mathrm{meq} / 100 \mathrm{~g} \mathrm{~K}$ at Atkapalia, Noakhali. The mean value of Sulphur was $2.978 \mathrm{mg} / \mathrm{L}$ which is used in the pharmaceuticals industry as well as agricultural practices. Chlorides get mixed into canal water from different point sources of industries of BSCIC and non-point sources of agricultural and municipal runoff. Temperature was in the acceptable limit according to ECR [3]. 
International Journal of Environmental Sciences \& Natural Resources

Table 2: Values of water quality parameters in Noakhali canal Noakhali, Bangladesh.

\begin{tabular}{|c|c|c|c|c|c|c|c|c|c|}
\hline Sample ID & pH & $\mathrm{EC}(\mu \mathrm{S} / \mathrm{cm})$ & TDS (mg/L) & $P(\mathrm{mg} / \mathrm{L})$ & $\mathrm{K}$ (cmol+) & $\begin{array}{c}\mathrm{SO}_{4}^{2-} \\
(\mathrm{mg} / \mathrm{L})\end{array}$ & $\mathrm{Cl}^{-}(\mathrm{mg} / \mathrm{L})$ & $\begin{array}{c}\mathrm{NaCl} \\
(\mathrm{mg} / \mathrm{L})\end{array}$ & $\mathrm{T}$ (Celsius) \\
\hline W-1 & 6.5 & 650 & 328 & 0.37 & 0.32 & 6.77 & 163.07 & 1.3 & 26.4 \\
\hline $\mathrm{W}-2$ & 6.7 & 660 & 332 & 0.68 & 0.3 & 2.01 & 167.32 & 1.6 & 26.8 \\
\hline$W-3$ & 6.55 & 770 & 377 & 1.18 & 0.39 & 1.47 & 191.43 & 1.5 & 26.9 \\
\hline W-4 & 6.7 & 1310 & 597 & 0.55 & 0.39 & 1.48 & 262.33 & 2.3 & 26.3 \\
\hline W-5 & 6.77 & 1320 & 635 & 0.63 & 0.39 & 3.69 & 347.41 & 2.5 & 26.8 \\
\hline W-6 & 6.8 & 1390 & 675 & 0.67 & 0.38 & 3 & 340.32 & 2.6 & 26.9 \\
\hline W-7 & 6.85 & 1420 & 691 & 0.65 & 0.41 & 2.56 & 368.68 & 2.1 & 26.9 \\
\hline W-8 & 6.72 & 1420 & 712 & 0.57 & 0.45 & 3.34 & 382.86 & 2.8 & 27 \\
\hline W-9 & 7.04 & 2690 & 1320 & 2.32 & 1.23 & 2.77 & 679.22 & 5.2 & 27.1 \\
\hline W-10 & 6.81 & 1390 & 682 & 0.73 & 0.4 & 2.69 & 380.25 & 2.7 & 27.3 \\
\hline Min & 6.5 & 650 & 328 & 0.37 & 0.3 & 1.47 & 163.07 & 1.3 & 26.3 \\
\hline Max & 7.04 & 2690 & 1320 & 2.32 & 1.23 & 6.77 & 679.22 & 5.2 & 27.3 \\
\hline Mean & 6.744 & 1302 & 634.9 & 0.835 & 0.466 & 2.978 & 328.289 & 2.46 & 26.84 \\
\hline SD & 0.152 & 572.081 & 286 & 0.56 & 0.271 & 1.519 & 151.753 & 1.098 & 0.298887 \\
\hline ECR (1997) & $6.5-8.5$ & 1200 & 2100 & - & - & - & - & - & - \\
\hline
\end{tabular}

$\mathrm{SD}=$ Standard Deviation, ECR= Environment Conservation Rules.

Determination of some trace metallic constituents in surface water of Noakhali Canal, Noakhali, Bangladesh

Table 3: Concentration of some selected heavy metallic constituents in surface water of Noakhali canal Noakhali, Bangladesh.

\begin{tabular}{|c|c|c|c|c|c|c|}
\hline Sample ID & Pd (mg/L) & $\mathrm{Cd}(\mathrm{mg} / \mathrm{L})$ & $\mathrm{Cu}(\mathrm{mg} / \mathrm{L})$ & $\mathrm{Fe}(\mathrm{mg} / \mathrm{L})$ & $\operatorname{Mn}(\mathrm{mg} / \mathrm{L})$ & $\mathrm{Zn}(\mathrm{mg} / \mathrm{L})$ \\
\hline W-1 & BDL & BDL & BDL & 0.071 & 0.004 & BDL \\
\hline $\mathrm{W}-2$ & BDL & BDL & BDL & 0.073 & 0.002 & BDL \\
\hline $\mathrm{W}-3$ & BDL & BDL & BDL & 0.083 & 0.46 & BDL \\
\hline W-4 & BDL & BDL & 0.014 & 3.77 & 1.033 & BDL \\
\hline W-5 & BDL & BDL & BDL & 0.074 & 0.001 & BDL \\
\hline W-6 & BDL & BDL & 0.011 & 0.073 & 0.507 & BDL \\
\hline W-7 & BDL & BDL & BDL & 0.18 & 1.501 & BDL \\
\hline W-8 & BDL & BDL & 0.01 & 0.058 & 0.012 & BDL \\
\hline W-9 & BDL & BDL & 0.011 & 0.096 & 0.028 & $\mathrm{BDL}$ \\
\hline W-10 & BDL & BDL & BDL & 1.022 & 0.533 & BDL \\
\hline Maximum & - & - & - & 3.77 & 1.501 & - \\
\hline Minimum & - & - & - & 0.058 & 0.001 & - \\
\hline Mean & - & - & - & 0.55 & 0.4081 & - \\
\hline SD & - & - & - & 1.169303 & & - \\
\hline DoE [3] & 0.05 & 0.005 & - & $0.3-1.0$ & 0.1 & 5 \\
\hline $\begin{array}{l}\text { WHO (1993) } \\
\text { guideline }\end{array}$ & 0.01 & 0.003 & - & NA & 0.5 & 3 \\
\hline USEPA [26] & NA & 0.005 & 0.5 & 0.3 & 0.05 & 5 \\
\hline DoE (27) & 0.05 & 0.5 & 0.5 & 2 & 5 & 5 \\
\hline
\end{tabular}

$\mathrm{SD}=$ Standard Deviation, BDL=Below Detection Limit, WHO=World Health Organization, USEPA= Unites States Environmental Protection Agency

The concentrations of heavy metals in water of Noakhali Canal has been given in Table 3. The mean concentrations of Fe and Mn were $0.55 \mathrm{mg} / \mathrm{L}$ and $0.4081 \mathrm{mg} / \mathrm{L}$, respectively. $\mathrm{Cu}$ was found in the very low concentration. $\mathrm{Pd}, \mathrm{Cd}$ and $\mathrm{Zn}$ were found below detection limit. Fe was higher than the acceptable limit of USEPA [25] guideline. Max Infrastructure Limited where Fe is used as a raw material which effluents may be the main reason of the high concentration of Fe including the natural sources.

Location of industries and their waste disposal system may be the responsible for variation of concentration of heavy metals [28]. 
Pearson's correlation co-efficient among water quality parameters and some selected trace metallic constituents in Noakhali canal.

Table 4: Correlation coefficients(r) among concentrations of water quality parameters and heavy metals of surface water in Noakhali Canal.

\begin{tabular}{|c|c|c|c|c|c|c|c|c|c|c|c|}
\hline & Temperature & pH & EC & TDS & $\mathbf{P}$ & $\mathbf{K}$ & $\mathrm{SO}_{4}{ }^{2-}$ & Cl & $\mathrm{NaCl}$ & $\mathbf{F e}$ & Mn \\
\hline Temperature & 1 & & & & & & & & & & \\
\hline $\mathrm{Ph}$ & 0.57 & 1 & & & & & & & & & \\
\hline EC & 0.449 & $.899^{* *}$ & 1 & & & & & & & & \\
\hline TDS & 0.481 & $.899^{* *}$ & $.998^{* *}$ & 1 & & & & & & & \\
\hline $\mathrm{P}$ & 0.443 & 0.613 & $.743^{*}$ & $.753^{*}$ & 1 & & & & & & \\
\hline $\mathrm{K}$ & 0.366 & $.726^{*}$ & $.892^{* *}$ & $.900^{* *}$ & $.929^{* *}$ & 1 & & & & & \\
\hline $\mathrm{SO}_{4}^{2-}$ & -0.267 & -0.306 & -0.171 & -0.147 & -0.281 & -0.092 & 1 & & & & \\
\hline $\mathrm{Cl}$ & 0.57 & $.905^{* *}$ & $.984^{* *}$ & $.991^{* *}$ & $.733^{*}$ & $.876^{* *}$ & -0.114 & 1 & & & \\
\hline $\mathrm{NaCl}$ & 0.486 & $.866^{* *}$ & $.976^{* *}$ & $.980^{* *}$ & $.789^{* *}$ & $.921^{* *}$ & -0.147 & $.968^{* *}$ & 1 & & \\
\hline $\mathrm{Fe}$ & -0.492 & -0.052 & 0.025 & -0.026 & -0.192 & -0.116 & -0.368 & -0.115 & -0.03 & 1 & \\
\hline $\mathrm{Mn}$ & -0.113 & 0.134 & 0.025 & -0.007 & -0.198 & -0.202 & -0.424 & -0.038 & -0.171 & 0.467 & 1 \\
\hline
\end{tabular}

**. Correlation is significant at the 0.01 level (2-tailed). * . Correlation is significant at the 0.05 level (2-tailed).

Pearson's correlation coefficient of heavy metals was studied using statistical software SPSS (version 22.0) which has been summarized in the Table 4. Correlation Co-efficient shows the significant positive correlation between EC-pH ( $\mathrm{r}=.899)$,TDS-pH $(\mathrm{r}=.899)$,TDS-EC $(\mathrm{r}=.998)$ at $\mathrm{p}<0.01$ level: P-EC $(=.743)$, P-TDS $(=.753)$ at $\mathrm{p}<0.05$ level; K-EC (=.892), K-TDS $(=.900)$, K-P (=.929) at $\mathrm{p}<0.01$ level, $\mathrm{K}-\mathrm{pH}(=.726)$ at $\mathrm{p}<0.05$ level; $\mathrm{Cl}-\mathrm{pH}(=.905), \mathrm{Cl}-$ $\mathrm{EC}(=.984)$, Cl-TDS (=.991), Cl-K $(=.8766)$ at $\mathrm{p}<0.01$ level whereas Cl-P (.733) at $\mathrm{p}<0.05$ level; NaCl-pH (=.866), NaCl-EC (.976), NaCl-TDS (=.980), NaCl-P (=.789), NaCl-K (=.921), NaCl-Cl (=.968) at

\section{Sediment quality of Noakhali Canal}

Table 5: Values of sediment quality parameters in Noakhali canal, Noakhali, Bangladesh.

\begin{tabular}{|c|c|c|c|c|c|c|c|c|}
\hline Sample ID & $\mathrm{pH}$ & $\mathrm{EC}(\mu \mathrm{S} / \mathrm{cm})$ & OC (\%) & OM (\%) & TN (\%) & $\mathbf{P}(\mu \mathrm{g} / \mathrm{g})$ & $\begin{array}{c}\mathrm{K} \\
\text { (meq/100gm) }\end{array}$ & $S(\mu \mathrm{g} / \mathrm{g})$ \\
\hline S-1 & 6.2 & 477 & 2.81 & 4.85 & 0.242 & 0.89 & 0.47 & 139.03 \\
\hline S-2 & 6.7 & 338 & 2.65 & 4.56 & 0.228 & 0.51 & 0.41 & 72.1 \\
\hline S-3 & 6.35 & 373 & 2.43 & 4.2 & 0.21 & 2.33 & 0.37 & 120.15 \\
\hline$S-4$ & 6.65 & 477 & 3.1 & 5.34 & 0.267 & 7.9 & 0.51 & 211.88 \\
\hline S-5 & 7.05 & 475 & 1.66 & 2.85 & 0.143 & 177.1 & 0.43 & 176.92 \\
\hline S-6 & 6.83 & 558 & 2.1 & 3.63 & 0.181 & 3.2 & 0.5 & 150.95 \\
\hline S-7 & 7.07 & 896 & 3.1 & 5.34 & 0.267 & 112.28 & 0.63 & 199.21 \\
\hline S-8 & 7.12 & 732 & 2.7 & 4.66 & 0.233 & 49.49 & 0.47 & 217.08 \\
\hline S-9 & 6.77 & 663 & 2.11 & 3.64 & 0.182 & 5.59 & 0.48 & 198.84 \\
\hline S-10 & 7.56 & 665 & 1.61 & 2.78 & 0.139 & 71.44 & 0.74 & 83.83 \\
\hline Min & 6.2 & 338 & 1.61 & 2.78 & 0.139 & 0.51 & 0.37 & 72.1 \\
\hline Max & 7.56 & 896 & 3.1 & 5.34 & 0.267 & 177.1 & 0.74 & 217.08 \\
\hline Mean & 6.83 & 565.5 & 2.427 & 4.185 & 0.21 & 43.1 & 0.5 & 157 \\
\hline SD & 0.394 & 172.91 & 0.541 & 0.933 & 0.046 & 60.627 & 0.108 & 52.524 \\
\hline $\begin{array}{l}\text { Standard for } \\
\text { Soil (SRDI, } \\
\text { 2012) }\end{array}$ & $6.6-7.4$ & - & - & $1.7-3.5$ & $0.181-0.28$ & $10.51-15.76$ & $0.181-0.28$ & $15.1-22.6$ \\
\hline
\end{tabular}

$\mathrm{SD}=$ Standard Deviation, SRDI=Soil Resource Development Institute

The significant correlations may reflect the fact that these chemicals had similar pollution levels and the similar pollution sources. From the correlation co-efficient, it is evident that increasing $\mathrm{pH}$ increased the concentration of EC, TDS, $\mathrm{K}, \mathrm{Cl}^{-}$and $\mathrm{NaCl}$. The rest of elemental pairs ( $\mathrm{Mn}$ and $\mathrm{Fe}$ ) showed no significant correlation with each other, suggesting that these metals are not associated with each other and lack of their identical behavior in aquatic environment. 
The values of physico-chemical parameters measured in Noakhali canal sediment at different sites have been given in Table 5. The mean values of $\mathrm{pH}, \mathrm{EC}, \mathrm{OC}, \mathrm{OM}, \mathrm{TN}, \mathrm{P}, \mathrm{K}, \mathrm{S}$ were $6.83,565.5$, $2.427 \%, 4.185 \%, 0.21 \%, 43.1 \mu \mathrm{g} / \mathrm{g}$, 0.5meq/100gm, $157 \mu \mathrm{g} / \mathrm{g}$, respectively. Values of $\mathrm{pH}$ was within the acceptable limit according to the SRDI (2012) standard soil quality. According to Chennakrisnan [29] the low $\mathrm{pH}$ values indicate the effluent from food industries. The mean value of EC was $565.5 \mu \mathrm{S} / \mathrm{cm}$. APHA [12] stated that a failing sewage system would raise the conductivity due to the presence of chloride, phosphate, and nitrate which may be the main reason of high concentration of EC. The mean value of OC was $2.427 \%$. Boyd [30] reported that OC value $0.60 \%-1.5 \%$ is highly suitable for aquaculture in Bangladesh. Where most of the value exceeded the normal values, which is highly detrimental to the aquatic organisms.

Ahmed [31] suggested that OC is increasing in the pond only for using supplementary feeds and it remains unused. Effluents from the several food industry and fish feed processing unit mix into the canal water which is responsible for getting high value of OC in the study area sediment. The mean value of OM was $4.185 \%$ and the coastal region contain the higher OM [32]. The presence of organic matter can influence the accumulation of heavy met- als in the sediment $[9,33]$. The mean concentration of TN was $0.21 \%$. Haque [33] estimated the range of nitrogen is $0.1 \%-0.3 \%$ in the coastal region of Bangladesh which support the good TN condition of canal water. The mean value of $\mathrm{P}$ was higher than the SRDI (2012) medium acceptable limit. Haque [33] suggested that the P range between $8-24 \mu \mathrm{g} / \mathrm{g}$ in soil is good for fish cultivation which does not support the present study. The main causes of high value of $\mathrm{P}$ in the canal water is industrial and municipal wastes [34] which support the present study. The mean value of $\mathrm{K}$ was $0.5 \mathrm{meq} / 100 \mathrm{gm}$. All values were higher in the acceptable limit according to the standard of SRDI (2012). Rahman \& Ahsan [33] estimated $\mathrm{K}$ at Atkapalia, Noakhali which mean value was $0.23 \mathrm{meq} / 100 \mathrm{gm}$. This value is lower than the present study. Figoni [35] stated that the base of $\mathrm{K}$ is also used to control the $\mathrm{pH}$. So, food industry is highly responsible for the high concentration of $\mathrm{K}$ in the canal sediment. The mean value of sulphur was very higher than the acceptable limit according to SRDI (2012) medium standard for soil. Rahman et al. [35] conducted an experiment in the farmer's field at Atkapalia, Noakhali during the winter season of 1999-2000and 2000-2001 under Farming Systems Research and Development (FSRD). The sulphur of soil was $65.2 \mu \mathrm{g} / \mathrm{g}$ in their estimation. Which does not support the present study.

\section{Measurement of heavy metals in sediment of Noakhali canal}

Table 6: Concentration of some selected heavy metallic constituents in sediment of Noakhali canal, Noakhali, Bangladesh

\begin{tabular}{|c|c|c|c|c|c|}
\hline Sample ID & Pd (mg/kg) & $\mathrm{Cu}(\mathrm{mg} / \mathrm{kg})$ & $\mathrm{Fe}(\mathrm{mg} / \mathrm{kg})$ & Mn (mg/kg) & $\mathrm{Zn}(\mathrm{mg} / \mathrm{kg})$ \\
\hline S-1 & 0.611 & 0.578 & 398.7 & 7.775 & 8.925 \\
\hline S-2 & 0.688 & 0.579 & 428.9 & 8.225 & 3.3 \\
\hline S-3 & 0.572 & 0.527 & 400.7 & 8.675 & 3.35 \\
\hline S-4 & 0.701 & 0.709 & 403.2 & 7.4 & 5.15 \\
\hline S-5 & 0.671 & 0.587 & 383.3 & 8.425 & 2.65 \\
\hline S-6 & 0.516 & 0.599 & 383.8 & 6.15 & 3.775 \\
\hline S-7 & 0.677 & 0.62 & 381.3 & 6.655 & 3.95 \\
\hline S-8 & 0.605 & 0.594 & 413.2 & 7.175 & 3.5 \\
\hline S-9 & 1.255 & 0.609 & 431 & 7.275 & 5.75 \\
\hline S-10 & 3.334 & 0.692 & 553 & 9.4 & 2.925 \\
\hline Maximum & 3.334 & 0.709 & 553 & 9.4 & 8.925 \\
\hline Minimum & 0.516 & 0.527 & 381.3 & 6.15 & 2.65 \\
\hline Mean & 0.936 & 0.6094 & 417.71 & 7.7155 & 4.3275 \\
\hline SD & 0.857 & 0.054 & 50.713 & 0.982 & 1.878 \\
\hline WHO (2004) SQG [37] & NA & - & NA & NA & 123 \\
\hline $\begin{array}{c}\text { USEPA (1999) SQG } \\
\text { [36] }\end{array}$ & 40 & - & 30 & 30 & 110 \\
\hline CCME (1999) SQG [38] & 35 & 26 & NA & NA & 123 \\
\hline $\begin{array}{c}\text { Typical content (Soil) } \\
{[40]}\end{array}$ & 32 & & - & 437 & 64 \\
\hline
\end{tabular}

$\mathrm{SD}=$ Standard Deviation, WHO=World Health Organization, USEPA= Unites States Environmental Protection Agency, SQG=Sediment Quality Guideline, Typical content (soil), Madejon et al., (2002).

The heavy metal concentrations in the study area sediment at all sampling sites have been given in Table 6. The order of heavy

metals concentration in sediment was $\mathrm{Fe}>\mathrm{Mn}>\mathrm{Zn}>\mathrm{Pb}>\mathrm{Cu}$. $\mathrm{Pd}$ and $\mathrm{Zn}$ were not found in the water sampling sites but was found 
in the sediment sampling sites. Pd and Zn may be absorbed onto the clay particles or it may uptake by biota. The mean concentration of Pd was $0.936 \mathrm{mg} / \mathrm{kg}$ which is released from industries and vehicles may travel long distances. The mean concentration of $\mathrm{Cu}$ was $0.6094 \mathrm{mg} / \mathrm{kg}$. The concentrations of Fe in every sampling site were very higher than the acceptable limit according to USEPA [36] SQLs. The mean concentration of Mn was $7.7155 \mathrm{mg} / \mathrm{kg}$. $\mathrm{Mn}$ is essential for many organisms as well as human which may be used in pharmaceuticals industry. The mean concentration of $\mathrm{Zn}$ was $4.3275 \mathrm{mg} / \mathrm{kg}$. Concentration of $\mathrm{Pd}, \mathrm{Cu}, \mathrm{Mn}$, Zn were in the acceptable limit comparing to the WHO [37], USEPA [36], CCME [38], SQLs \& Madejon et al. [39] typical content of soil. Though the mean and high concentration of heavy metals were below the WHO [37], USEPA [36], CCME [38] and the soil typical content, they might be concentrated in the course of time [40] where Fe was higher than the acceptable limit.

\section{Pearson's correlation co-efficient among sediment quality parameters and some selected heavy metallic constituents in Noakhali Canal}

Table 7: Correlation coefficients among concentrations of sediment quality parameters and heavy metals of surface water in Noakhali canal.

\begin{tabular}{|c|c|c|c|c|c|c|c|c|c|c|c|c|c|}
\hline & pH & EC & OC & OM & TN & $\mathbf{P}$ & $\mathbf{K}$ & $\mathbf{S}$ & $\mathbf{P b}$ & $\mathrm{Cu}$ & $\mathrm{Fe}$ & Mn & $\mathrm{Zn}$ \\
\hline pH & 1 & & & & & & & & & & & & \\
\hline EC & 0.599 & 1 & & & & & & & & & & & \\
\hline OC & -0.467 & 0.098 & 1 & & & & & & & & & & \\
\hline OM & -0.469 & 0.099 & $1.000^{* *}$ & 1 & & & & & & & & & \\
\hline TN & -0.467 & 0.099 & $1.000^{* *}$ & $1.000^{* *}$ & 1 & & & & & & & & \\
\hline $\mathbf{P}$ & 0.598 & 0.378 & -0.346 & -0.351 & -0.347 & 1 & & & & & & & \\
\hline $\mathbf{K}$ & $.710^{*}$ & $.670^{*}$ & -0.154 & -0.154 & -0.155 & 0.287 & 1 & & & & & & \\
\hline$S$ & 0.033 & 0.516 & 0.348 & 0.347 & 0.349 & 0.227 & -0.05 & 1 & & & & & \\
\hline $\mathbf{P b}$ & $.646^{*}$ & 0.249 & -0.556 & -0.555 & -0.555 & 0.138 & $.762^{*}$ & -0.415 & 1 & & & & \\
\hline $\mathrm{Cu}$ & 0.513 & 0.332 & 0.016 & 0.014 & 0.014 & 0.097 & $.728^{*}$ & 0.185 & 0.562 & 1 & & & \\
\hline $\mathrm{Fe}$ & 0.564 & 0.115 & -0.476 & -0.475 & -0.475 & -0.034 & $.637^{*}$ & -0.518 & $.960^{* *}$ & 0.493 & 1 & & \\
\hline Mn & 0.141 & -0.423 & -0.46 & -0.461 & -0.459 & 0.173 & 0.069 & -0.629 & 0.58 & 0.019 & $.635^{*}$ & 1 & \\
\hline $\mathrm{Zn}$ & $-.637^{*}$ & -0.057 & 0.411 & 0.413 & 0.41 & -0.455 & -0.099 & 0.171 & -0.203 & -0.016 & -0.2 & -0.236 & 1 \\
\hline
\end{tabular}

**. Correlation is significant at the 0.01 level (2-tailed). *. Correlation is significant at the 0.05 level (2-tailed).

Pearson's correlation coefficient among different sediment quality parameters and heavy metals are presented in Table 7. Correlation co-efficient shows the positive significant between several elements' pairs OM-OC $(=1.00), \mathrm{TN}-\mathrm{OC}(=1.00), \mathrm{TN}-\mathrm{OM}$ $(=1.00)$, Fe-Pd (=.960) at $\mathrm{p}<0.01$ level. And Pd-pH (=.646), Pd-K

\section{Assessment of sediment heavy metals contamination}

\section{Geo-accumulation index}

Table 8: Geo-accumulation Index (Igeo) values of heavy metals of the canal sediment.

\begin{tabular}{|c|c|c|c|c|c|}
\hline Samples Site & Pd & Cu & Fe & Mn & -2 \\
\hline S-1 & -1.823 & -2.0043 & 1.885 & -2 & -1.07 \\
\hline S-2 & -1.769 & -2.0043 & 1.916 & -2 & -1.522 \\
\hline S-3 & -1.853 & 2.0043 & 1.887 & -2.055 & -1.522 \\
\hline S-4 & -1.769 & -1.9208 & 1.889 & -2 & -1.309 \\
\hline S-5 & -1.795 & -2.0043 & 1.868 & -1.13 & -1.455 \\
\hline S-6 & -1.92 & -2.0043 & 1.8686 & -2.102 & -1.424 \\
\hline S-7 & -1.777 & -2 & 1.866 & -2.296 & -1.481 \\
\hline S-8 & -1.826 & -2 & 1.9 & -2.296 & -1.267 \\
\hline S-9 & -1.522 & -2 & 1.919 & -1.95 & -1.568 \\
\hline S-10 & -1.086 & -0.9586 & 2.027 & & \\
\hline
\end{tabular}

Karbassi et al. [41] stated that Igeo values have been used to explain sediment quality. According to the Muller [15] formu-
(=.762), Cu-K (=.728), Fe-K (=.637), Mn-Fe (=.635) at $\mathrm{p}<0.05$ level. It also shows a negative correlation coefficient with $\mathrm{Zn}-\mathrm{pH}$ $(=-.635)$ at $\mathrm{p}<0.05$ level. The Pearson correlation suggests that increasing $\mathrm{pH}$ results $\mathrm{Pd}$ accumulation in sediment. la, the calculated results of Igeo values of the sediment are given in Table 8. According to Muller [18] scale (Table 1), a qualitative 
scale of pollution intensity [42]. Igeo values of $\mathrm{Pd}, \mathrm{Cu}, \mathrm{Zn}$ and $\mathrm{Mn}$ were below 0 (zero) that indicates class 0 (zero) and sediment from canal is unpolluted for these measured heavy metals. Igeo

\section{Contamination factor (CF)}

Table 9: Contamination Factor (CF), Contamination Degree (CD) and ePollution Load Index (PLI) values.

\begin{tabular}{|c|c|c|c|c|c|c|c|}
\hline \multirow{2}{*}{ Sample ID } & \multicolumn{7}{|c|}{ Contamination Factor (CF) } \\
\cline { 2 - 8 } & Pd (mg/Kg) & Cu (mg/Kg) & Fe (mg/Kg) & Mn (mg/Kg) & Zn (mg/Kg) & $\begin{array}{c}\text { Degree of } \\
\text { Contamination } \\
\text { (CD) }\end{array}$ & $\begin{array}{c}\text { Pollution Load } \\
\text { Index (PLI) }\end{array}$ \\
\hline S-1 & 0.03055 & 0.012844 & 0.008447 & 0.009147 & 0.093947 & 0.154936 & 0.019539 \\
\hline S-2 & 0.0344 & 0.012867 & 0.009087 & 0.009676 & 0.034737 & 0.100767 & 0.016834 \\
\hline S-3 & 0.0286 & 0.011711 & 0.008489 & 0.010206 & 0.035263 & 0.09427 & 0.015922 \\
\hline S-4 & 0.03505 & 0.015756 & 0.008542 & 0.008706 & 0.054211 & 0.122264 & 0.0186 \\
\hline S-5 & 0.03355 & 0.013044 & 0.008121 & 0.009912 & 0.027895 & 0.092522 & 0.015793 \\
\hline S-6 & 0.0258 & 0.013311 & 0.008131 & 0.007235 & 0.039737 & 0.094215 & 0.015168 \\
\hline S-7 & 0.03385 & 0.013778 & 0.008078 & 0.007829 & 0.041579 & 0.105115 & 0.016509 \\
\hline S-8 & 0.03025 & 0.0132 & 0.008754 & 0.008441 & 0.036842 & 0.097488 & 0.016116 \\
\hline S-9 & 0.06275 & 0.013533 & 0.009131 & 0.008559 & 0.060526 & 0.1545 & 0.020931 \\
\hline S-10 & 0.1667 & 0.015378 & 0.011716 & 0.011059 & 0.030789 & 0.235642 & 1.1434 \\
\hline Mean & 0.0786 & 0.0135 & 0.0088 & 0.009 & 0.0455 & 0.025232 \\
\hline
\end{tabular}

Contamination factor of sediment sampling sites is shown in the Table 9. Maximum degree of contamination is 0.236 in S-10 sampling site. All the sampling sites have contamination factor (CF) >1 indicating low concentration for all tested heavy metals. The mean values of contamination factor for all sampling sites were $(\mathrm{CF})>1$ indicating low concentration. On the basis of the mean values of $\mathrm{CF}$, sediment is enriched for metals in the following order: $\mathrm{Pd}>\mathrm{Zn}>\mathrm{Cu}>\mathrm{Mn}>\mathrm{Fe}$.

\section{Pollution load index}

The PLI represents the number of times by which the metal content in the sediment exceeds the background concentration. It gives a summative indication of the overall level of heavy metal toxicity in a particular sampling site [2]. According to the Tomlinson et al. [21] formula, the calculated PLI values of all sampling sites are presented in Table 9. The PLI ranged from 0.015 to 0.025 . The present study showed that the PLI values of all sampling sites were lower than 1. It indicates no pollution. The PLI can provide some understanding to the public of the area about the quality of a component of their environment [42].

\section{Conclusion}

According to the scientific literature and to the best of our knowledge this is the first study which provide information on heavy metals pollution of Noakhali canal Noakhali, Bangladesh. The following conclusions can be drawn from the present study: Compare to the investigated data with different national and international guidelines, it is evident that the canal is in good condition with lower level of heavy metal contamination except higher level of Fe contamination in sediment and water which could mainly be attributed to geological and industrial sources. value of Fe was 1-2 that indicates that the sediment of canal is unpolluted to moderately polluted for Fe.
This study clearly demonstrated the quality of canal water and sediment surrounding the industrial and municipal areas which will provide useful information to the policy maker and policy planner of the People's Republic of Bangladesh for the pollution control as well as implement sustainable strategies to keep the canal free from domestic and industrial effluents.

\section{References}

1. Duman F, Aksoy A, Demirezen D (2007) Seasonal variability of heavy metals in surface sediment of Lake Sapanca, Turkey. Environ Monit Assess 133(1-3): 277-283.

2. Barakat A, El Baghdadi M, Rais J, Nadem S (2012) Assessment of heavy metal in surface sediment of Day River at Beni-Mellal region, Morocco. Res J Environ. Earth Sci 4(8): 797-806.

3. DoE (1997) Environment conservation rules, E.C.R. schedule 3, standards for water. Department of Environment, Bangladesh.

4. Rabbani G, Sharif MI (2005) Dhaka city: state of environment (SOE) 2005. UNEP in collaboration with BCAS and DoE, 40.

5. Chowdhury M, Mostafa MG, Biswas TK, Mandal A, Saha AK (2015) Characterization of the effluents from leather processing industries. Environ Process 2(1): 173-187.

6. Fernandes C, Fontaínhas-Fernandes A, Cabral D, Salgado MA (2008) Heavy metals in water, sediment and tissues of Liza saliens from Esmoriz-Paramos lagoon, Portugal. Environ Monit Assess 136(1-3): 267-275.

7. Mondal S, Rahman MM, Saha D, Adhikary RK, Hossain MB (2013) Present status of good aquaculture practices (GAP) in shrimp farms of southwestern coastal area, Bangladesh. Middle-East Journal of Scientific Research 14(6):873-878.

8. Pravakar P, Sarker BS, Rahman M, Hossain MB (2013) Present status of fish farming and livelihood of fish farmers in shahrasti upazila of Chandpur district, Bangladesh. Am Eur J Agr Environ Sci 13(3): 391397. 
9. Hossain MB, Rahman M (2017) Ocean Acidification: an impending disaster to benthic shelled invertebrates and ecosystem. J Noak Sci Tec Univ 1(1): 19-30.

10. Manoj K, Kumar B, Padhy PK (2012) Characterisation of Metals in Water and Sediment of Subarnarekha River along the Projects' Sites in Lower Basin, India. Univers j environ res technol 2(5).

11. Singh L, Choudhary SK, Singh PK (2012) Status of heavy metal concentration in water and sediment of river Ganga at selected sites in the middle Ganga plain. Int J Res Chem Environ 2(4): 236-243.

12. Banglapedia ND (2008) National Encyclopedia of Bangladesh Website.

13. APHA, A.W.W.A. (1998) WEF (American Public Health Association, American Water Works Association, and Water Environment Federation). Standard methods for the examination of water and wastewater, 19.

14. Jumbe AS, Nandini N (2009) Heavy metals analysis and sediment quality values in urban lakes. Am J Environ Sci 5(6): 678-687.

15. Huq SI, Alam MD (2005) A handbook on analyses of soil, plant and water. BACER-DU, University of Dhaka, Bangladesh, p. 246.

16. Muller G (1969) Index of geoaccumulation in sediment of the Rhine River. Geo Journal 2(3): 108-118.

17. Amin B, Ismail A, Arshad A, Yap CK, Kamarudin MS (2009) Anthropogenic impacts on heavy metal concentrations in the coastal sediment of Dumai, Indonesia. Environ Monit Assess 148(1): 291-305.

18. Qingjie G, Jun D, Yunchuan X, Qingfei W, Liqiang Y (2008) Calculating pollution indices by heavy metals in ecological geochemistry assessment and a case study in parks of Beijing. J Chin Univ Geosci 19(3): 230-241

19. Muller G (1981) The heavy metal pollution of the sediment of Neckars and its tributary: a stocktaking. Chemiker-Zeitung. 105: 157-164.

20. Hakanson L (1980) An ecological risk index for aquatic pollution control. A sedimentological approach. Water Res 14(8): 975-1001.

21. Ahdy HH, Khaled A (2009) Heavy metals contamination in sediment of the western part of Egyptian Mediterranean Sea. Aust J Basic \& Appli Sci 3(4): 3330-3336.

22. Tomlinson DL, Wilson JG, Harris CR, Jeffrey DW (1980) Problems in the assessment of heavy-metal levels in estuaries and the formation of a pollution index. Helgoländer Meeresuntersuchungen 33(1-4): 566575

23. Harikumar PS, Nasir UP, Rahman MM (2009) Distribution of heavy metals in the core sediment of a tropical wetland system. Int J Environ Sci Technol 6(2): 225-232.

24. Nadia MA (2006) Study on effluents from selected sugar mills in Pakistan: Potential environmental, health, and economic consequences of an excessive pollution load: Sustainable Development Policy Institute. Islamabad, Pakistan.

25. Stone NM, Thomforde HK (2004) Understanding your fish pond water analysis report. Cooperative Extension Program., University of Arkansas at Pine Bluff, US Department of Agriculture and county governments cooperating.
26. USEPA (2008) National primary drinking water standards. United States Environmental Protection Agency.

27. DoE (2008) Guide for Assessment of Effluent Treatment Plants.

28. Alam K (2003) Cleanup of the Buriganga River: Integrating the environment into decision making., (Doctoral dissertation, Murdoch University).

29. Chennakrishnan C, Stephen A, Manju T, Raveen R (2008) Water Quality status of three vulnerable freshwater Lakes of Suburban Chennai, India. Ind J Environ Ecoplan 15(3): 591-596.

30. Boyd CE (1995) Soils in pond aquaculture. In Bottom Soils, Sediment, and Pond Aqua, pp. 1-9.

31. Ahmed H (2004) Soil Quality Analysis and Considerations in the selection of sites for sustainable Aquaculture in South East Coast of Chittagong Specially Halishahar Area., M. Sc. Thesis Institute of Marine Science and Fisheries, University of Chittagong. Chittagong, Bangladesh. p. 80.

32. Egna HS, Boyd CE (1997) Dynamics of pond aquaculture. CRC press, USA.

33. Haque SA (2006) Salinity problems and crop production in coastal regions of Bangladesh. Pak J Bot 38(5): 1359-1365.

34. Wang L, Liang T (2014) Effects of exogenous rare earth elements on phosphorus adsorption and desorption in different types of soils. Chemosphere 103: 148-155.

35. Figoni PI (2010) How baking works: exploring the fundamentals of baking science. John Wiley \& Sons, USA.

36. USEPA (1999) Screening level ecological risk assessment protocol for hazardous waste combustion facilities, Appendix E: Toxicity reference values. United States Environmental Protection Agency.

37. WHO (2004) Guidelines for Drinking Water Quality. ( $3^{\text {rd }}$ edn), World Health Organization, p. 515.

38. CCME (1999) Canadian water quality guidelines for protection of aquatic life. Canadian Water Quality Index 1.0, Technical Report, Canadian Environmental Quality Guidelines.

39. Madejón P, Murillo JM, Marañón T, Cabrera F, López R (2002) Bioaccumulation of $\mathrm{As}, \mathrm{Cd}, \mathrm{Cu}, \mathrm{Fe}$ and $\mathrm{Pb}$ in wild grasses affected by the Aznalcóllar mine spill (SW Spain). Sci Total Environ 290(1-3): 105120.

40. Begum M, Huq SI (2016) Heavy metal contents in soils affected by industrial activities in a southern district of Bangladesh. Bangladesh J Sci Res 29(1): 11-17.

41. Karbassi AR, Monavari SM, Nabi Bidhendi GR, Nouri J, Nematpour K (2008) Metal pollution assessment of sediment and water in the Shur River. Environ Monit Assess 147(1-3): 107-116.

42. Mohiuddin KM, Zakir HM, Otomo K, Sharmin S, Shikazono N (2010) Geochemical distribution of trace metal pollutants in water and sediment of downstream of an urban river. Int J Environ Sci Tech 7(1): 17-28. 
(C) This work is licensed under Creative DOI: 10.19080/IJESNR.2019.17.555963
Your next submission with Juniper Publishers will reach you the below assets

- Quality Editorial service

- Swift Peer Review

- Reprints availability

- E-prints Service

- Manuscript Podcast for convenient understanding

- Global attainment for your research

- Manuscript accessibility in different formats ( Pdf, E-pub, Full Text, Audio)

- Unceasing customer service

Track the below URL for one-step submission https://juniperpublishers.com/online-submission.php 